\title{
Antibiotic Levels in Pericardial Fluid
}

\author{
James S. Tan, John C. Holmes, Noble O. Fowler, George T. Manitsas, and \\ John P. Phatr \\ From the Infectious Disease Division and the Division of Cardiology, \\ Department of Internal Medicine, University of Cincinnati College of Medicine, \\ Cincinnati, Ohio 45229
}

\begin{abstract}
A B S T R A C T An experimental model was designed to study the ability of antibiotics to enter the pericardial compartment. Noninfected and infected pericardial fluid and serum antibiotic activities were determined in adult mongrel dogs before and at intervals after antibiotic administration. After the administration of penicillin $G$, methicillin, cephaloridine, streptomycin, or gentamicin, clinically adequate antibiotic levels in the noninfected pericardial fluid were obtained within $1 \mathrm{~h}$, and these levels approached or exceeded the serum levels within 2-4 h. Antibiotic levels obtained from infected dog pericardial fluids were higher than those from noninfected animals. Patients' serum and pericardial fluid antibiotic levels were measured after penicillin G, penicillin $\mathrm{V}$, cephalothin, and gentamicin administration. We have found, both in the canine and human studies, that pericardial antibiotic levels taken at least $2 \mathrm{~h}$ after antibiotic administration are almost identical to those in the blood.
\end{abstract}

\section{INTRODUCTION}

Antimicrobial therapy of bacterial pericarditis with or without surgical drainage has successfully cured this infection, often lethal in the preantibiotic era (1). Information on the entry of antibiotics and other substances into the pericardial sac is scarce. Stewart, Crane, Dietrick injected phenolsulfonphthalein and vital red intravenously and failed to recover these dyes in the pericardial fluid of a patient with tuberculous pericarditis (2). Ory, Meads, Brown, Wilcox, and Finland (3) demonstrated penicillin in the pericardial fluid after intramuscular administration in a patient with streptococcal purulent pericarditis. Wolfe, Lepper, Caldwell, Spies, and Dowling (4) reported pericardial chlortetracycline levels to be $5-200 \%$ that of serum in two patients. Geraci, Heilman, and Nichols demonstrated sig-

\footnotetext{
Received for publication 14 August 1972 and in revised form 4 September 1973.
}

nificant vancomycin levels in pericardial fluids of 14 patients (5). Riff and Jackson (6) found pericardial gentamicin levels to be half of the serum concentration in a patient. Serial studies to determine the rate of entry of antibiotics into pericardial fluid are not available in the literature.

A review of purulent pericarditis by Boyle, Pearce, and Guze showed that staphylococcus, pneumococcus, streptococcus, meningococcus, Hemophilus influenzae, and enteric gram-negative rods were the major causative organisms in the 425 cases reported in the literature up to 1959 (1). In the present study, antibiotics frequently effective against these bacteria and $M$. tuberculosis were evaluated by studying the diffusion of antibiotics into sterile and infected pericardial fluid in a dog model. In addition, limited serial observations of penicillin, cephalothin, and gentamicin levels in human pericardial fluid are presented.

\section{METHODS}

Experimental model. Adult mongrel dogs were anesthetized with $25.0 \mathrm{mg} / \mathrm{kg}$ of sodium pentobarbital intramuscularly. With aseptic surgical techniques, the chest was opened on the left side at the fourth intercostal space and the pericardial sac was entered through a stab wound. The proximal end of a green Kifa catheter (United States Catheter \& Instrument Co., Glen Falls, N. Y.) was inserted into the pericardial cavity. The catheter was filled with heparin $(500 \mathrm{U} / \mathrm{ml})$, and the distal end closed with Luerlock Plug (Becton-Dickinson \& Co., Rutherford, N. J.) and buried under the skin. After 7 days, the dogs were anesthetized in a similar manner and the pericardial catheters were re-exposed through a small skin incision. The pericardial fluid was removed and the pericardial sac washed once with $75-100 \mathrm{ml}$ of sterile isotonic saline. The catheter was clamped after the reinjection of $75-100 \mathrm{ml}$ of saline into the pericardial space. After $1 \mathrm{~h}, 10 \mathrm{ml}$ of blood was drawn and simultaneously $10 \mathrm{ml}$ of fluid from the pericardial sac was removed from the catheter as the preantibiotic sample, and the test antibiotic was administered intramuscularly. At $30 \mathrm{~min}, 1,2,3,4,5$, and $6 \mathrm{~h}$, samples were obtained from the pericardial catheter and simultaneous blood samples collected from the femoral 
TABLE I

Pericardial Fluid/Serum Antibiotic Concentration Ratio in Experimental Animals

\begin{tabular}{|c|c|c|c|c|c|c|c|}
\hline \multirow[b]{2}{*}{ Antibiotic } & \multicolumn{5}{|c|}{ Hours } & \multirow{2}{*}{$\begin{array}{c}\% \\
\text { Protein } \\
\text { bound }\end{array}$} & \multirow[b]{2}{*}{ References } \\
\hline & $1 / 2$ & 1 & 2 & 3 & 4 & & \\
\hline \multicolumn{8}{|l|}{ Penicillin G } \\
\hline Noninfected & 0.03 & 0.18 & 0.49 & 0.72 & 0.69 & $59-65$ & (9) \\
\hline Infected & 0.23 & 0.50 & 1.00 & 1.6 & 1.4 & & \\
\hline \multicolumn{8}{|l|}{ Methicillin } \\
\hline Noninfected & 0.10 & 0.31 & 0.90 & 1.12 & 1.21 & 49 & (9) \\
\hline Infected & 1.2 & 3.5 & 4.0 & $*$ & $*$ & & \\
\hline \multicolumn{8}{|l|}{ Cephaloridine } \\
\hline Noninfected & 0.11 & 0.18 & 0.74 & 1.40 & 1.75 & $21-24$ & (10) \\
\hline Infected & 0.47 & 0.96 & 0.66 & 0.88 & 1.00 & & \\
\hline \multicolumn{8}{|l|}{ Streptomycin } \\
\hline Noninfected & 0.05 & 0.35 & 1.25 & 0.93 & 1.01 & 30 & (11) \\
\hline Infected & 0.36 & 1.20 & 1.50 & 1.70 & 2.40 & & \\
\hline \multicolumn{8}{|l|}{ Gentamicin } \\
\hline Noninfected & 0.57 & 0.65 & 1.04 & 1.32 & 1.47 & $0-30$ & $(12,13)$ \\
\hline Infected & 1.2 & 3.4 & 3.2 & $*$ & $*$ & & \\
\hline
\end{tabular}

* Ratio not computed; serum level 'not detectable by the assay method used.

vein. All samples from pericardial fluid at 0 and $6 \mathrm{~h}$ were blood-tinged and contained less than $2.5 \mathrm{~g}$ of protein $/ 100$ $\mathrm{ml}$. The serum of the dogs before and at $6 \mathrm{~h}$ after the administration of antibiotics had creatinine levels from 1.0 to $1.7 \mathrm{mg} / 100 \mathrm{ml}$.

To produce infection in the pericardial fluid, $2 \mathrm{ml}$ of $S$. aureus $502 \mathrm{~A}$ suspension (containing $10^{8}$ colony-forming $\mathrm{U} / \mathrm{ml}$ ) were instilled into the pericardial sac 1 wk after the placement of the pericardial catheter. The experimental animals became ill by the third to the fifth day after the introduction of the bacteria. On the seventh day, antibiotics were administered and samples were obtained from the blood and pericardial fluid as described in the preceding paragraph. Two animals were infected and studied for each antibiotic. The pericardial fluid removed before the instillation of saline had a packed red cell volume of $2.0-3.0 / 100$ $\mathrm{ml}$, and $45,000-374,000$ leukocytes $/ \mathrm{mm}^{3}$ with $70-80 \%$ neutrophils, and the protein content was between 5 and $6 \mathrm{~g} / 100$ $\mathrm{ml}$. Culture of this fluid yielded $S$. aureus. The fluid from the pericardial space obtained $6 \mathrm{~h}$ after antibiotic instillation yielded concentrations of $3.0-3.6 \mathrm{~g} / 100 \mathrm{ml}$. Tissues obtained from the pericardium of an animal showed diffused polymorphonuclear leukocyte infiltration of the pericardial fat and gram-positive cocci.

Antibiotics. The following antibiotics were given intramuscularly to dogs : $15,000 \mathrm{U} / \mathrm{kg}$ of penicillin $\mathrm{G}(\mathrm{E}$. $\mathrm{R}$. Squibb \& Sons, Princeton, N. J.), $30 \mathrm{mg} / \mathrm{kg}$ of methicillin (Bristol Laboratories, Div. of Bristol-Myers Co., Syracuse, N. Y.), $10 \mathrm{mg} / \mathrm{kg}$ of cephaloridine (Eli Lilly and Company, Indianapolis, Ind.), $1 \mathrm{mg} / \mathrm{kg}$ of gentamicin (Schering Corporation, Bloomfield, N. J.), and $10 \mathrm{mg} / \mathrm{kg}$ of streptomycin (Eli Lilly and Company.).

Serum and pericardial fluid were assayed for antibiotic levels by the agar diffusion method of Bennett, Brodie, Benner, and Kirby, with Bacillus subtilis spore suspension (Difco Laboratories, Detroit, Mich.) as the test organism (7). Pooled homologous serum and phosphate-buffered saline were used for dilution of standards for the measurement of serum and pericardial fluid antibiotic concentrations, respectively.

Patients. Informed consent for the study was obtained from four patients with pericarditis and persistent reaccumulation of pericardial fluid. A catheter was placed in the pericardial space as a therapeutic procedure to prevent cardiac tamponade. Patients M. B. and C. T. had chronic glomerulonephritis, W. L. had tuberculous pericarditis, and G. W. had metastatic adenocarcinoma. Serum and pericardial samples were obtained before the intramuscular or oral administration of antibiotics and at different intervals thereafter.

The samples from patients M. B., C. T., and W. L. were assayed by the two-fold tube dilution method with Bacillus subtilis as the test organism (8). The samples obtained from G. W. were assayed with agar diffusion technique (7).

\section{RESULTS}

\section{Animals with noninfected pericardium}

Four animals were used for each drug study. Figs. 1-5 present the results of the individual serum and pericardial fluid antibiotic levels as well as the geometric mean concentrations. The pericardial fluid to serum ratio $(\mathrm{P} / \mathrm{S})^{\mathrm{x}}$ during the first $4 \mathrm{~h}$ of study is shown in Table I.

Penicillin G. (Fig. 1, Table I). The mean peak serum level was reached at $30 \mathrm{~min}$ and that of the pericardial fluid at $2 \mathrm{~h}$ after penicillin $\mathrm{G}$ administration. During the

\footnotetext{
${ }^{1}$ Abbreviation used in this paper: $\mathrm{P} / \mathrm{S}$, pericardial fluid-
} to-serum ratio. 


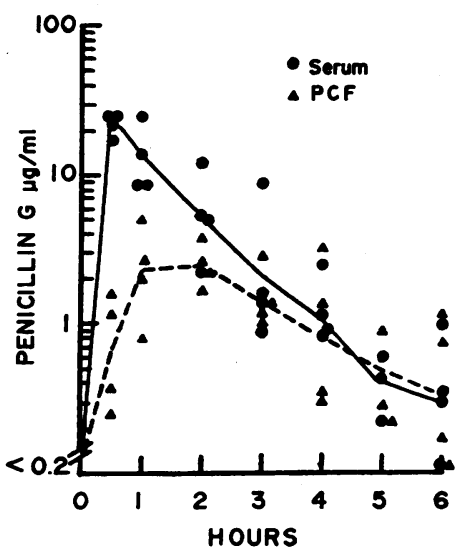

FIGURE 1 Serum and pericardial fluid antibiotic levels in four dogs after $15,000 \mathrm{U} / \mathrm{kg}$ of penicillin $\mathrm{G}$ intramuscularly.

first $4 \mathrm{~h}, \mathrm{P} / \mathrm{S}$ did not exceed 0.50 . At 5 and $6 \mathrm{~h}, \mathrm{P} / \mathrm{S}$ exceeded 1.00 .

Methicillin. (Fig. 2, Table I). At 30 min, the mean peak serum level was achieved, and that of pericardial fluid at $2 \mathrm{~h} . \mathrm{P} / \mathrm{S}$ was 0.31 at $1 \mathrm{~h}$ and surpassed 1.00 by $3 \mathrm{~h}$.

Cephaloridine. (Fig. 3, Table I). At $1 \mathrm{~h}$, the serum and pericardial fluid of two dogs were not available for assay. The peak serum level was attained between 30 min and $1 \mathrm{~h}$. The mean pericardial fluid level peaked at $2 \mathrm{~h}$. Within the first $\mathrm{h}, \mathrm{P} / \mathrm{S}$ was only 0.18 , but it exceeded 1.00 at $3 \mathrm{~h}$.

Gentamicin. (Fig. 4, Table I). The mean peak serum and pericardial fluid concentration of gentamicin was reached by $1 \mathrm{~h}$. Unlike the other antibiotics tested in this study, gentamicin had a $\mathrm{P} / \mathrm{S}$ greater than 0.50 within $30 \mathrm{~min}$. As with streptomycin, P/S exceeded 1.00 by $2 \mathrm{~h}$.

Streptomycin. (Fig. 5, Table I). Only three animals were studied with this drug. The mean peak level in the

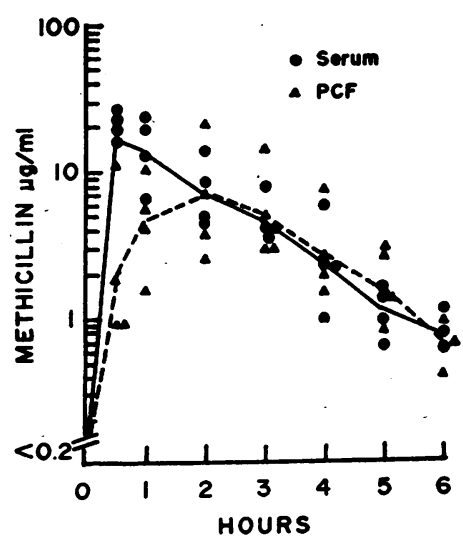

FIgURE 2 Serum and pericardial fluid antibiotic levels in four dogs after $30 \mathrm{mg} / \mathrm{kg}$ of methicillin intramuscularly.

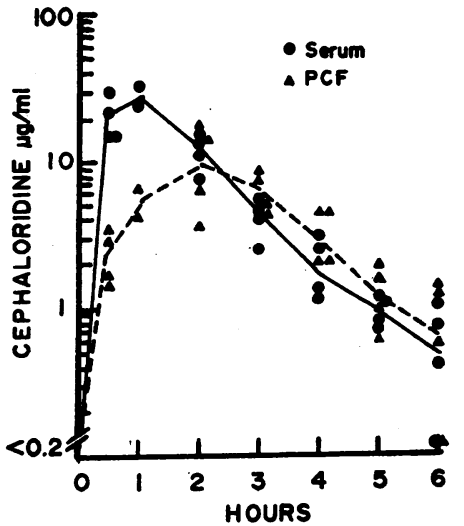

Figure 3 Serum and pericardial fluid antibiotic levels in four dogs after $10 \mathrm{mg} / \mathrm{kg}$ of cephaloridine intramuscularly.

serum was achieved at $1 \mathrm{~h}$, and that of the pericardial fluid at $2 \mathrm{~h}$. In spite of the low $\mathrm{P} / \mathrm{S}$ during the first $\mathrm{h}$, the ratio was greater than 1.00 by $2 \mathrm{~h}$.

\section{Animals with infected pericardial fluid}

The antibiotic levels in the serum and infected pericardial fluid are shown in Table II. High antibiotic levels were attained within $30 \mathrm{~min}$ to $1 \mathrm{~h}$. Except with cephaloridine, the antibiotic levels in infected pericardial fluid were consistently higher than those in uninfected fluid, hence, there was a higher $\mathrm{P} / \mathrm{S}$ (Table I).

\section{Clinical studies (Table III)}

Three patients were each given 1 million $U$ of penicillin G intramuscularly. W. L., who had normal renal function, had measurable pericardial fluid antibiotic levels within $30 \mathrm{~min}$. At $2 \mathrm{~h}$ the pericardial fluid penicillin $G$ concentration was one dilution higher than that

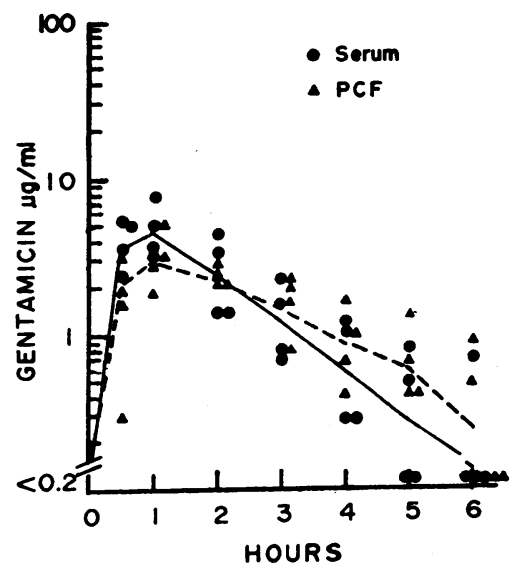

FIgURE 4 Serum and pericardial fluid antibiotic levels in four dogs after $1 \mathrm{mg} / \mathrm{kg}$ of gentamicin intramuscularly.

Antibiotic Levels in Pericardial Fluid 


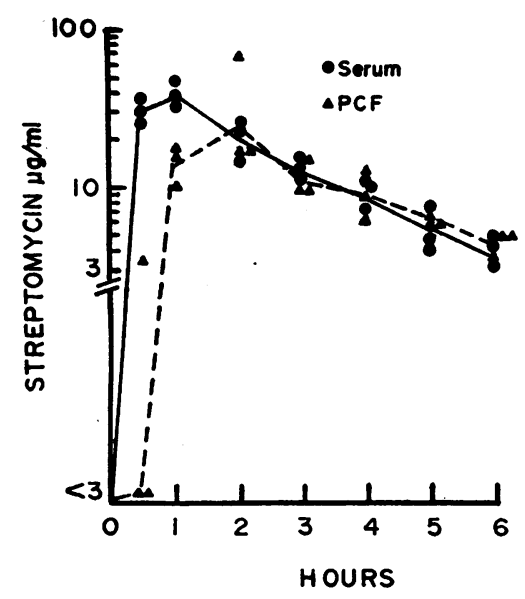

Figure 5 Serum and pericardial fluid antibiotic levels in three dogs after $10 \mathrm{mg} / \mathrm{kg}$ of streptomycin intramuscularly.

of the serum. In the two patients (M. D. and C. T.) with poor renal function (serum creatinine greater than $14 \mathrm{mg} / 100 \mathrm{ml}$ ), penicillin $\mathrm{G}$ activity was detected in the pericardial fluid within $30 \mathrm{~min}$ and came to within one dilution of the serum level in $2-4 \mathrm{~h}$. The pericardial fluid and serum levels were identical $48 \mathrm{~h}$ after antibiotic administration. A fourth patient was given gentamicin; pericardial fluid levels exceeded that of the serum within $2 \mathrm{~h}$.

On separate occasions, studies of other antibiotics were carried out. W. L. received $625 \mathrm{mg}$ of penicillin V orally. The pericardial levels exceeded the serum levels from $2 \mathrm{~h}$ after injection. M. B. was given $250 \mathrm{mg}$ of cephalothin intramuscularly. At $2-5 \mathrm{~h}$, the serum and pericardial cephalothin levels were equal.

\section{DISCUSSION}

All five antibiotics studied in the experimental model readily entered the noninfected and acutely infected pericardial fluid compartment and similar results were demonstrated in the patients after a single dose of antibiotics. In the noninfected pericardial fluid, the peak serum levels at no time were exceeded by those of the pericardial fluid. $2 \mathrm{~h}$ after antibiotic administration, the pericardial drug levels approached or exceeded those of the serum (Figs 1-5 and Table I). The initial lag probably represents the time necessary for the diffusion of the antibiotic across the membrane. The penicillin $G$ and cephaloridine levels in the infected fluid did not exceed the peak serum levels, attained within $30 \mathrm{~min}$. The $\mathrm{P} / \mathrm{S}$ ratios of methicillin and gentamicin were greater than 1.0 at $30 \mathrm{~min}$. These findings may be due to the attainment of peak serum levels earlier than $30 \mathrm{~min}$, or to a sampling error. The higher $\mathrm{P} / \mathrm{S}$ found in the infected pericardial fluid may be explained by increased rate of entry secondary to acute inflammation, or by blood leaking into the pericardial cavity.

Studies of penicillin G levels were extended up to 48 $h$ in the two patients with renal failure. Serum and pericardial fluid levels were essentially similar after equilibrium was attained. From the studies of the noninfected pericardial fluid, the results indicate that the entry of the antibiotics into this compartment was by diffusion rather than active transport.

TABLE II

Diff usability of Antibiotics into the Infected Dog Pericardial Fluid

\begin{tabular}{|c|c|c|c|c|c|c|}
\hline & & \multicolumn{5}{|c|}{ Antibiotic levels } \\
\hline & & $1 / 2$ & 1 & 2 & 3 & 4 \\
\hline & & & & $\mu g / m l$ & & \\
\hline \multirow[t]{2}{*}{ Penicillin G } & PCF & 2.2 & 4.0 & 2.8 & 2.5 & 1.6 \\
\hline & Serum & 9.6 & 8.0 & 2.8 & 1.6 & 1.1 \\
\hline \multirow[t]{2}{*}{ Methicillin } & $\mathrm{PCF}$ & 18.0 & 21.8 & 8.4 & 5.0 & $*$ \\
\hline & Serum & 14.6 & 6.2 & 2.1 & $<1.0$ & \\
\hline \multirow[t]{2}{*}{ Cephaloridine } & PCF & 7.4 & 14.5 & 7.3 & 5.2 & 3.4 \\
\hline & Serum & 15.8 & 15.1 & 11.1 & 5.9 & 3.4 \\
\hline \multirow[t]{2}{*}{ Streptomycin } & PCF & 10.9 & 35.4 & 31.6 & 30.1 & 22.0 \\
\hline & Serum & 30.0 & 29.0 & 21.0 & 17.6 & 9.1 \\
\hline \multirow[t]{2}{*}{ Gentamicin } & PCF & 2.3 & 3.4 & 2.59 & 1.4 & $*$ \\
\hline & Serum & 1.9 & 1.0 & 0.79 & $<0.4$ & \\
\hline
\end{tabular}

* Antibiotic level not detectable by the assay method used. PCF, pericardial fluid. 
TABLE III

Pericardial and Serum Antibiotic Levels of Four Patients

\begin{tabular}{|c|c|c|c|c|c|c|c|c|}
\hline Patients & Diagnosis & Antibiotics & $\begin{array}{l}\text { Hours } \\
\text { after }\end{array}$ & $\begin{array}{l}\text { Serum } \\
\text { antibiotic } \\
\text { levels }\end{array}$ & $\begin{array}{c}\text { PCF } \\
\text { antibiotic } \\
\text { levels }\end{array}$ & BUN & $\begin{array}{l}\text { Serum } \\
\text { creatinine }\end{array}$ & Other data \\
\hline W. L. & $\begin{array}{l}\text { Tuberculous } \\
\text { pericarditis }\end{array}$ & $\begin{array}{l}\text { Penicillin G } \\
1 \text { million U } \\
\text { i.m. }\end{array}$ & $\begin{array}{l}0 \\
1 / 2 \\
1 \\
2 \\
4 \\
6\end{array}$ & $\begin{array}{c}\mu g / m l \\
<0.01 \\
12.5 \\
12.5 \\
3.12 \\
0.78 \\
0.4\end{array}$ & $\begin{array}{r}\mu g / m l \\
<0.01 \\
3.12 \\
6.25 \\
6.25 \\
3.12 \\
0.78\end{array}$ & $\begin{array}{c}m g / 100 m l \\
18\end{array}$ & $\begin{array}{c}m g / 100 m l \\
1.2\end{array}$ & $\begin{array}{l}\text { PCF protein } \\
\quad=6.0 \mathrm{~g}\end{array}$ \\
\hline M. B. & $\begin{array}{l}\text { Chronic glomerulo- } \\
\text { nephritis }\end{array}$ & $\begin{array}{l}\text { Penicillin G } \\
1 \text { million U } \\
\text { i.m. }\end{array}$ & $\begin{array}{l}0 \\
1 / 2 \\
1 \\
2 \\
4 \\
6 \\
8 \\
12 \\
24 \\
48\end{array}$ & $\begin{array}{c}<0.01 \\
12.5 \\
25.0 \\
50.0 \\
25.0 \\
25.0 \\
25.0 \\
25.0 \\
6.25 \\
0.78\end{array}$ & $\begin{array}{c}<0.01 \\
3.12 \\
6.25 \\
25.0 \\
25.0 \\
25.0 \\
25.0 \\
25.0 \\
3.12 \\
0.78\end{array}$ & 116 & 14.0 & $\begin{array}{l}\text { PCF specific } \\
\qquad \text { gravity }=1.025\end{array}$ \\
\hline C. T. & $\begin{array}{l}\text { Chronic glomerulo- } \\
\text { nephritis }\end{array}$ & $\begin{array}{l}\text { Penicillin G } \\
1 \text { million U } \\
\text { i.m. }\end{array}$ & $\begin{array}{l}0 \\
1 / 2 \\
1 \\
2 \\
4 \\
6 \\
8 \\
24 \\
48\end{array}$ & $\begin{array}{c}<0.01 \\
12.5 \\
12.5 \\
50.0 \\
50.0 \\
25.0 \\
25.0 \\
12.5 \\
1.56\end{array}$ & $\begin{array}{c}<0.01 \\
1.56 \\
3.12 \\
6.25 \\
25.0 \\
25.0 \\
25.0 \\
6.25 \\
1.56\end{array}$ & 68 & 16.5 & $\begin{array}{c}\text { PCF protein } \\
=3.3 \mathrm{~g} \\
\end{array}$ \\
\hline W. L. & $\begin{array}{l}\text { Tuberculous } \\
\text { pericarditis }\end{array}$ & $\begin{array}{l}\text { Penicillin V } \\
625 \mathrm{mg} \text { orally }\end{array}$ & $\begin{array}{l}0 \\
1 / 2 \\
1 \\
2 \\
4 \\
6\end{array}$ & $\begin{array}{c}<0.01 \\
12.5 \\
6.25 \\
1.56 \\
0.20 \\
0.05\end{array}$ & $\begin{array}{r}<0.01 \\
0.78 \\
0.20 \\
3.12 \\
1.56 \\
0.40\end{array}$ & 12 & 1.3 & \\
\hline M. B. & $\begin{array}{l}\text { Chronic glomerulo- } \\
\text { nephritis }\end{array}$ & $\begin{array}{l}\text { Cephalothin } \\
250 \text { mg i.m. }\end{array}$ & $\begin{array}{l}0 \\
1 / 2 \\
1 \\
2 \\
3 \\
4 \\
5\end{array}$ & $\begin{array}{l}<0.01 \\
25.0 \\
25.0 \\
12.5 \\
12.5 \\
12.5 \\
12.5\end{array}$ & $\begin{array}{c}<0.01 \\
6.25 \\
12.5 \\
12.5 \\
12.5 \\
12.5 \\
12.5\end{array}$ & 120 & 26.8 & \\
\hline G. W. & $\begin{array}{l}\text { Metastatic adeno- } \\
\text { carcinoma }\end{array}$ & $\begin{array}{l}\text { Gentamicin } \\
1.7 \mathrm{mg} / \mathrm{kg}\end{array}$ & $\begin{array}{l}0 \\
1 \\
2 \\
3 \\
4\end{array}$ & $\begin{array}{r}<0.5 \\
3.8 \\
3.3 \\
1.9 \\
1.5\end{array}$ & $\begin{array}{r}<0.5 \\
3.5 \\
4.0 \\
3.5 \\
2.5\end{array}$ & & 1.1 & $\begin{array}{l}\text { PCF protein } \\
=7.3 \mathrm{mg} / 100 \mathrm{ml}\end{array}$ \\
\hline
\end{tabular}

PCF, pericardial fluid; BUN, blood urea nitrogen.

As in the studies on uninfected interstitial fluids (14), the ability of a particular antibiotic to enter the noninfected pericardium appeared to be related to the percentage of antibiotic bound to protein. Penicillin G, which has the highest percentage of protein binding among the five antibiotics studied, was found to have the lowest $\mathrm{P} / \mathrm{S}$ ratio. In contrast, cephaloridine, streptomycin, and gentamicin, which are less protein-bound, had the higher $\mathrm{P} / \mathrm{S}$ ratio. This relationship was not observed in the infected pericardium, where the protein content was higher. The antibiotics, except cephaloridine, were observed to enter more readily.
This study shows that measurable levels of antibiotics can be attained in acutely infected and noninfected pericardial fluid after intramuscular drug administration. Attainable penicillin, methicillin, and cephalosporin levels in the serum and pericardial fluid were far above the minimal inhibitory concentration for the growth of majority of gram-positive cocci (staphylococcus, pneumococcus, and streptococcus) (15). The mean peak gentamicin level after the administration of $1 \mathrm{mg} / \mathrm{kg}$ in the infected and uninfected dogs was close to the cut-off point between microbial susceptibility and resistance $(5 \mu \mathrm{g} / \mathrm{ml})(16)$. If $1.5-2 \mathrm{mg} / \mathrm{kg}$ of gentamicin is given, 
higher serum levels can be expected. Streptomycin levels obtained in the infected and uninfected dogs were much higher than those needed to inhibit sensitive strains of Mycobacterium tuberculosis (16). Serum obtained at least 1-2 $\mathrm{h}$ after antibiotic administration contained drug concentrations closely approximating that found in the infected pericardial fluid for all the antibiotics studied. In clinical situations, assay of serum levels of these antibiotics can be used to estimate whether or not the pericardial fluid concentration of the antibiotic is likely to be at a bactericidal level.

\section{ACKNOWLEDGMENTS}

We appreciate the excellent technical assistance of Thomas W. P. Bannister and Mrs. Marjorie Gabel.

This work was supported in part by Eli Lilly and Company, Indianapolis, Ind., and Training Grants T1 AI 87; HL 5445; HL 5776: and Program Project Grant HL 6307 from the United States Public Health Service.

\section{REFERENCES}

1. Boyle, J. D., M. L. Pearce, and L. B. Guze. 1961 Purulent pericarditis: a review of literature and report of eleven cases. Medicine (Baltimore). 40: 119.

2. Stewart, H. J., N. F. Crane, and J. E. Deitrick. 1938. Absorption from pericardial cavity in man. Am. Heart J. 16: 198

3. Ory, E. M., M. Meads, B. Brown, C. Wilcox, and M. Finland. 1945. Penicillin levels in serum and in some body fluids during systemic and local therapy. J. Lab. Clin. Med. 30: 809.

4. Wolfe, C. K., Jr., M. H. Lepper, E. R. Caldwell, Jr., H. W. Spies, and H. F. Dowling. 1952. Treatment of non-tuberculosis bacterial pleural space infections with aureomycin: results of treatment in 9 patients; con- centration of aureomycin in pleural and pericardial fluid in patients. Ann. Intern. Med. 37: 164.

5. Geraci, J. E., F. R. Heilman, D. R. Nichols, W. B. Wellman, and G. T. Ross. 1957. Some laboratory and clinical experiences with a new antibiotic, vancomycin. Antibiot. Annu. 90.

6. Riff, L. J., and G. G. Jackson. 1971. Pharmacology of gentamicin in man. J. Infect. Dis. 124: S98.

7. Bennett, J. V., J. L. Brodie, E. J. Benner, and W. M. M. Kirby. 1966. Simplified accurate method for antibiotic assay of clinical specimens. Appl. Microbiol. 14: 170.

8. Henderson, W. R., J. Carleton, and M. Hamburger. 1962. The effect of probenecid upon serum levels of methicillin. Am. J. Med. Sci. 243: 489.

9. Rolinson, G. N., and R. Sutherland. 1965. The binding of antibiotics to serum proteins. Br. J. Pharmacol. 25: 638.

10. Naumann, P. 1967. Bacteriological and pharmacological properties of cephalothin and cephaloridine. Postgrad. Med.J. 43: 26, (Suppl.).

11. Scholtan, W., and J. Schmid. 1962. Binding of antibiotics to serum protein. II. The protein binding of tetracycline and other antibiotics with the exception of the penicillins. Arznemittel-Forschung. 13: 287.

12. Black, J,. B. Calesnick, D. Williams, and M. J. Weinstein. 1964. Pharmacology of gentamicin, a new broadspectrum antibiotic. Antimicrob. Agents Chemother. 138.

13. Gordon, R. C., C. Regamey, and W. M. M. Kirby. 1972. Serum protein binding of aminoglycoside antibiotics. Antimicrob. Agents Chemother. 2: 214.

14. Tan, J. S., A. Trott, J. P. Phair, and C. Watanakunakorn. 1972. A method for measurement of antibiotics in human interstitial fluid. J. Infect. Dis. 126: 492.

15. Garrod, L. P., and F. O'Grady. 1971. Antibiotics and Chemotherapy. E. and S. Livingstone, Ltd., Edinburgh. 3rd edition. 72.

16. Kirby, W. M. M., and H. C. Standiford. 1969. Gentamicin: in vitro studies. J. Infect. Dis. 119: 361. 